\title{
AKTIVITAS KATALITIK EKSTRAK KUNYIT PUTIH SEBAGAI PENGATAS PENYAKIT KANKER
}

Nurmaya*1

${ }^{1}$ Pendidikan Kimia,FMIPA, Universitas Negeri Padang, Indonesia

* E-mail : nmaya190599@gmail.com

Abstrak. Study ini bertujuan untuk membuat ekstrask kunyit putih ${ }^{(1)}$ yang berguna untuk menyembuhkan penyakit. Metode yang dilakukan adalah eksperimen dan uji aktivitas katalitik ${ }^{(2)}$ secara langsung. Tahapan pertama dilakukan dengan pembuatan ekstrak dari kunyit putih $^{(3)}$. Uji aktivitas langsung dilakukan dengan variasi selama rentang waktu 10x peminuman. Hasil eksperimen membuktikan bahwa ekstrak kunyit putih dapat menyembuhkan penyakit kanker tersebut ${ }^{(4)}$. Penyembuhan ini di duga karena adanya aktivitas katalitik ${ }^{(5)}$ ekstrak kunyit putih terhadap sel tubuh. ${ }^{(6)}$

Kata kuci: ekstrak, kunyit putih, penyakit kanker, sakit perut, sel tubuh.

\section{Pendahuluan}

Begitu sangat penting reaksi kimia ${ }^{(7)}$ dalam kehidupan. Dimanapun reaksi kimia dapat terjadi. Di perut, mata, mulut reaksi kimia pun terjadi. Reaksi kimia ${ }^{(8)}$ terjadi pada mahkluk hidup,(manusia,hewan, tumbuhan) dan juga di alam, Suatu reaksi kimia ${ }^{(9)}$ akan menghasilkan produk baru dengan sifat baru ${ }^{(10)}$. Reaksi kimia dapat terjadi secara spontan maupun tidak, cepat ataupun lambat. Reaksi kimia sangatlah penting bagi kehidupan, besar sekali pengaruh reaksi kimia dalam kehidupan kita $^{(11)}$.

Ada 5 ciri penanda reaksi kimia, yang pertama yaitu adanya perubahan warna, apabila dua zat atau lebih di reaksikan dapat menghasilkan warna maka tanda reaksi kimia telah berlangsung, yang kedua yaitu adanya bau,adanya bau juga merupakan tanda adanya reaksi kimia, yang ketiga yaitu terjadinya perubahan suhu, naik atau turunnya suhu juga merupakan ciri dari reaksi kimia, 
yang keempat adanya endapan, adanya endapan merupakan tanda adanya reaksi kimia yang terjadi,dan yang terakhir yaitu terbentuknya gelembung gas, adanya gelembung gas merupakan tanda adanya reaksi kimia ${ }^{(12)}$.

Selain itu, sangat erat kaitan antara reaksi kimia dengan katalitik. Katalitik merupakan faktor yang mempercepat reaksi tanpa ikut bereaksi. Pada katalitik ada yang disebut dengan herbal katalis. Herbal katalis biasanya digunakan untuk membantu pengobatan dengan cara tradisional $^{(13)}$.herbal katalis berupa sampel alam, baik itu buah $^{(14)}$ maupun sayur ${ }^{(15)}$.. Pengobatan dengan herbal katalis juga dapat menyembuhkan penyakit berat.

Salah satu katalis herbal yaitu kunyit putih, kunyit putih merupakan salah satu obat herbal yang dikenal oleh orang tua zaman dahulu dapat menyembuhkan penyakit kanker ${ }^{(16)}$. Bukan hanya dipercaya oleh orang tua zaman dahulu, namun masih dianggap demikian oleh orang-orang zaman sekarang. Penanaman tumbuhan kunyit putih tidak susah apabila di tanam di daerah padang, Tanaman ini hanya tumbuh pada tempat tertentu ${ }^{(17)}$.

Pada kunyit putih, yang dapat di jadikan sebagai obat penyakit kanker ${ }^{(18)}$ adalah ekstraknya. Ekstrak dari kunyit putih ini nantinya akan bereaksi dengan sel tubuh yang tidak normal, sehingga membantu menstabilkan sel-sel yang bermasalah. diduga kunyit putih mengandung zat ribosome inactivating protein (RIP) yang dapat menempel pada sel tubuh yang tidak normal, sehingga sel-sel bermasalah dalam tubuh yang seharusnya berkembang diberhentikan karena aktivitas dari menempelnya zat ribosome inactivating protein (RIP) ${ }^{(18)}$.

Pada study ini akan membahas tentang bagaimana katalitik herbal dari kunyit putih dapat digunakan sebagai obat penyakit kanker dengan hasil eksperimen pengalaman seseorang yang telah melakukannya secara langsung ${ }^{(19)}$. Sehingga dapat dibuktikan bahwa peran kunyit putih 
sebagai katalitik herbal benar adanya ${ }^{(20)}$. Sehingga nantinya dapat di manfaatkan lagi keberadaan obat-obat herbal yang ada di sekitar kita ${ }^{(21)}$. terutama kunyit putih. Di samping penanamannya yang mudah, pembuatan ekstrak nya juga tidak rumit. Selain itu perubahan dapat di rasakan setelah melakukan peminuman ekstrak ini ${ }^{(22)}$.

\section{Metode}

a). Alat dan bahan

Peralatan yang dipakai adalah gelas (king), parutan (lion star), panci perebus air(stainless steel), sendok (stainless steel)

Bahan yang digunakan adalah Kunyit putih (diambil dari daerah pegambiran,Sumatra barat ), dan air (Le-Minerale)
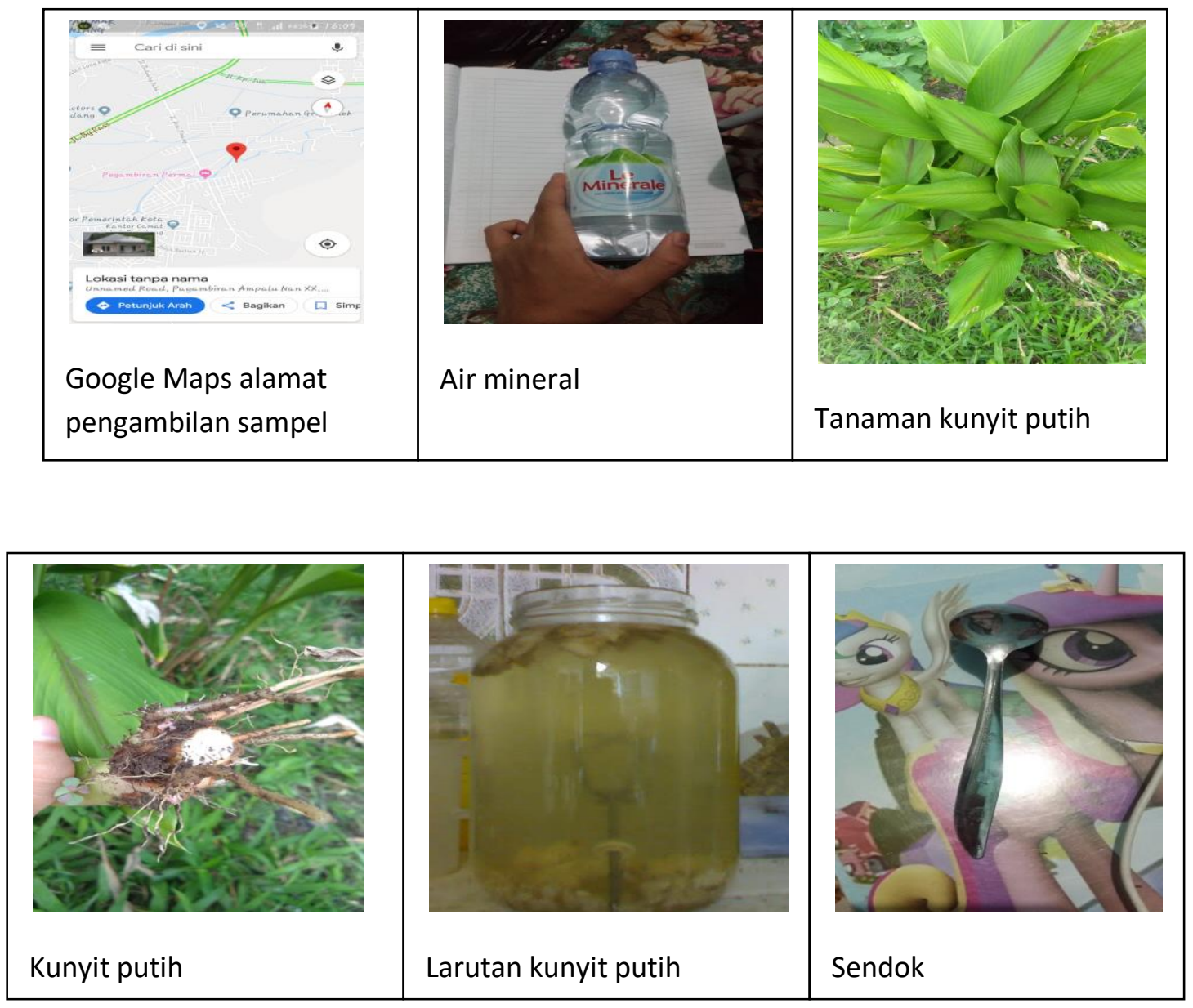


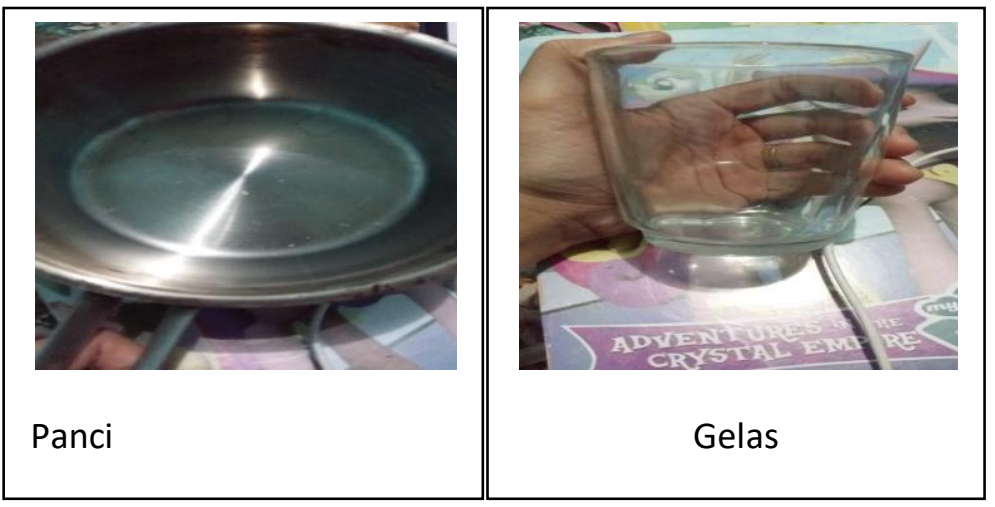

b). Prosedur kerja

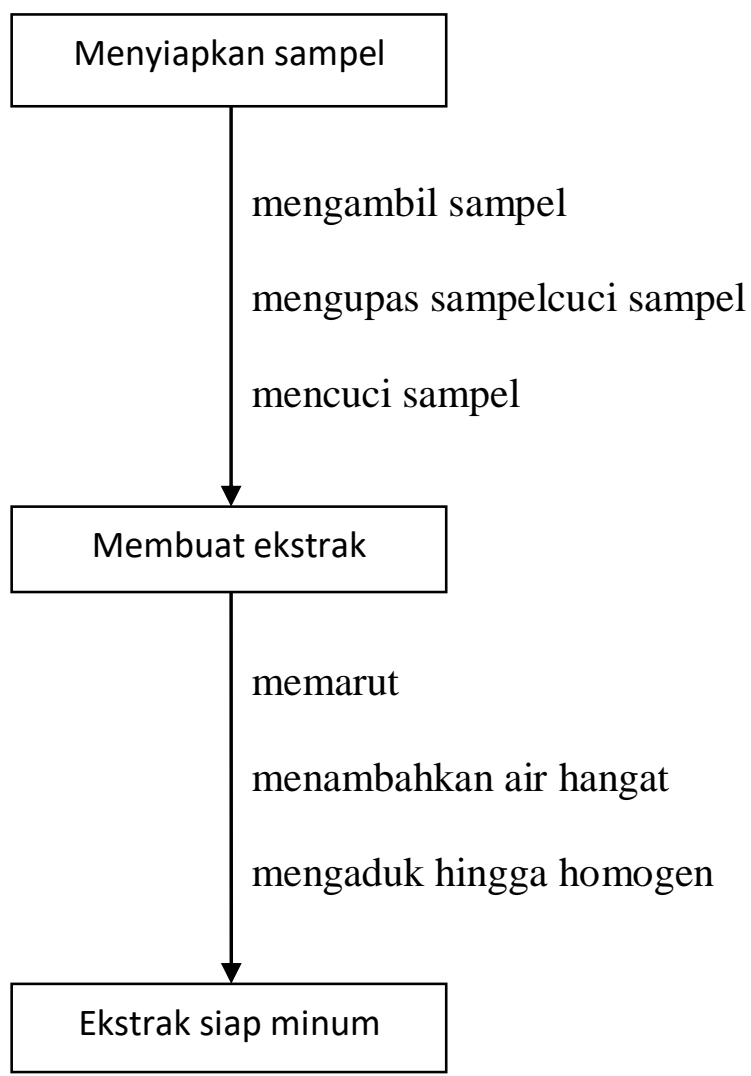


c). Pengujian ekstrak

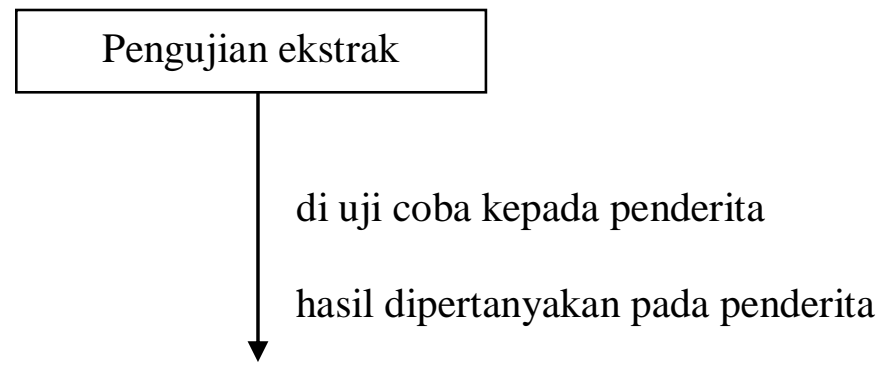

d). Pengujian terakhir

menurut keterangan penderita kanker ia menyatakan bahwa setelah $10 \mathrm{x}$ peminuman, benjolan kanker pada payudara nya menghilang dan dokter tidak menemukan lagi adanya penyakit kanker pada payudaranya

\section{Hasil}

i. Hasil pembuatan

Pembuatan hasil ekstrak kunyit putih dari 10 gram dalam $200 \mathrm{ml}$ air di peroleh ekstrak sebanyak 1 gelas dapat dilihat dari gambar berikut ini

ii. Hasil uji coba

Pengujian terhadap orang penderita kanker ternyata berhasil seperti keterangan berikut ini: 


\begin{tabular}{|c|c|}
\hline Peminuman & Besar benjolan \\
\hline 1 & 5 \\
\hline 2 & 5 \\
\hline 3 & 4 \\
\hline 4 & 3 \\
\hline 5 & 3 \\
\hline 6 & 2 \\
\hline 7 & 2 \\
\hline 8 & 1 \\
\hline 9 & 0 \\
\hline 10 & \\
\hline
\end{tabular}

Ket:

5= benjolan besar keras, 4=benjolan besar, 3=benjolan mengecil, 2=benjolan kecil, 1=benjolan mulai menghilang, $0=$ benjolan tidak ada lagi. 


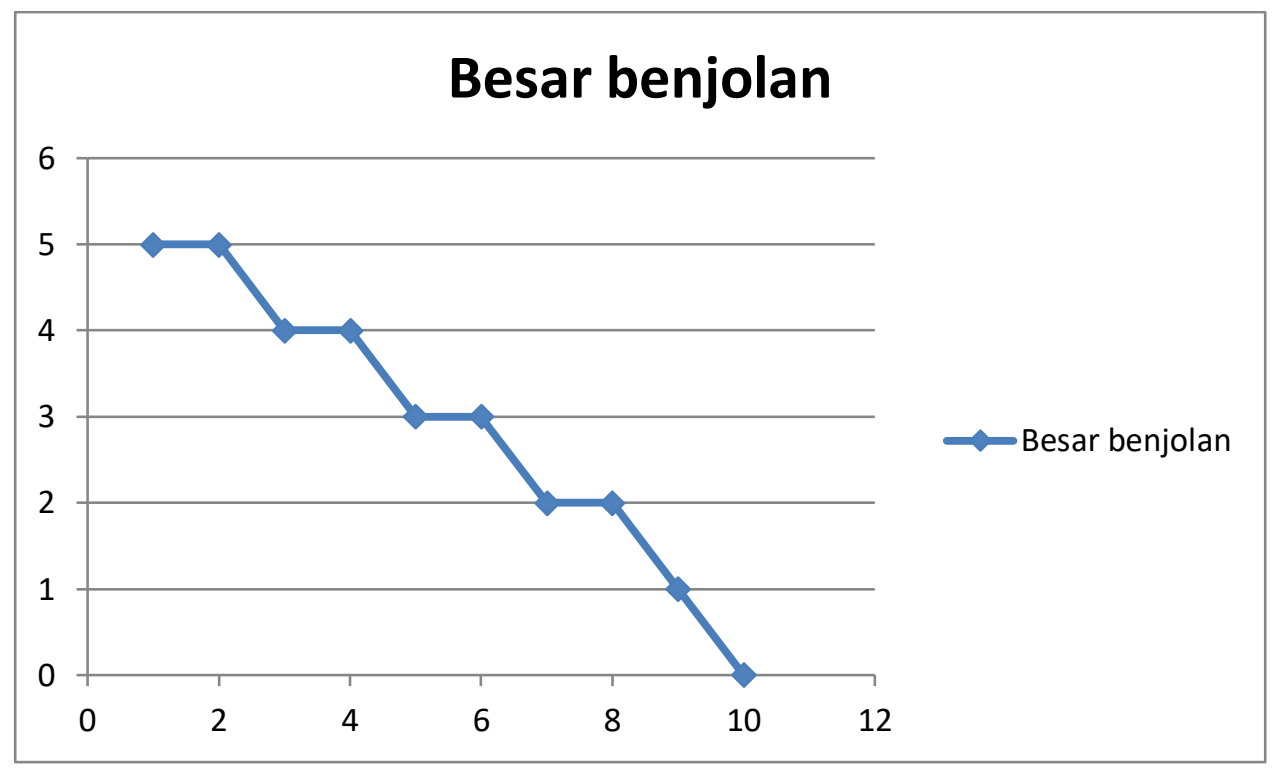

\section{Pembahasan}

Ekstraksi digunakan dalam pembuatan ekstrak kunyit putih, yang mana pada percobaan kunyit putih berfungsi sebagai herbal katalis untuk penyembuhan penyakit kanker. Sebanyak 10 gram kunyit putih yang telah di gerus di larutkan dengan air sebanyak $200 \mathrm{ml}$, yang kemudian dapat langsung di minum. $200 \mathrm{ml}$ air dan 10 gram kunyit putih yang telah homogen ini setara dengan satu gelas. Pemanfaatan ekstrak kunyit putih sebagai obat herbal tradisional yang ampuh dalam penyembuhan penyakit kanker bukan hanya diketahui oleh orang tua zaman dahulu,namun saat ini pun telah banyak orang yang mengetahuinya. Pada proses pembuatan ekstrak kunyit putih tidak 
terdapat kendala yang signifikan, karena tumbuhan ini mudah untuk dicari dan pembuatannya yang tidak rumit ${ }^{(23)}$.

Kunyit putih mempunyai nama latin curcuma mangga val. tumbuh berupa semak, berumur tahunan ${ }^{(24)}$. Mempunyai daun berwarna hijau yang pada bagian tengahnya terdapat warna kecoklatan di daunnya. Bentuk daunnya mirip dengan tumbuhan kunyit kuning, dan pada akar nya lah kunyit putih tersimpan ${ }^{(25)}$. Tinggi dari tumbuhan ini berkisar 40-60 cm. dipercaya tumbuhan ini mengandung banyak khasiat. Karena telah di buktikan melalui eksperimen seseorang yang mencobanya ${ }^{(26)}$.

Khasiat yang terkandung pada tumbuhan kunyit putih yaitu dapat menyembuhkan penyakit kanker seperti yang dibahas pada eksperimen ini,namun selain mengatasi ini, kunyit putih juga di percaya dapat menyembuhkan penyakit-penyakit lainnya,seperti wasir, penurun panas, masuk angin, gatal-gatal, diare, dan masih banyak lagi ${ }^{(27)}$. Kunyit putih sebagai katalitik herbal dapat menyembuhkan penyakit kanker dan juga sakit perut pada wanita haid karena adanya zat ribosome inactivating protein (RIP), zat ini berfungsi untuk memberhentikan perkembangan sel yang bermasalah ${ }^{(28)}$. Mekanismenya yaitu dengan menempel pada sel yang berkembang biak itu ${ }^{(29)}$. Meskipun hanya memberhentikan perkembangan sel, namun pengaruhnya sangat besar, karena sel yang telah lama tidak berkembang biak pada akhirnya akan mati ${ }^{(30)}$.

Pada eksperimen telah dibuktikan bahwa kunyit putih dapat menyembuhkan penyakit kanker ${ }^{(31)}$. seorang penderita kanker payudara membuktikan bahwa hal ini benar 
adanya. Penderita penyakit ini adalah tetangga di sebelah rumah dengan lokasi di pegambiran, ia menyatakan setelah di diagnosa oleh dokter mengalami sakit kanker payudara tahap awal ia teringat oleh orang tuanya yang menyatakan bahwa kunyit putih dapat menyembuhkan penyakit kanker. Sehingga ia mencoba untuk menggunakan kunyit putih agar penyakitnya dapat hilang, tanpa harus melaukan kemoterapi ${ }^{(32)}$. Ia berhasil membuktikan bahwa setelah 10x peminuman berturut-turut dengan jumlah satu gelas setiap harinya, penyakit kanker nya hilang ${ }^{(33)}$. Dan pernyataan ini di akui juga oleh dokternya. Meskipun ia mengakui berat rasanya setiap hari harus menghabisi ekstrak kunyit putih yang pahitnya tidak tertahan ${ }^{(34)}$. Dan sampai saat ini ia selalu meminumnya meskipun ia telah dinyatakan bebas kanker oleh dokter ${ }^{(35)}$.. Benjolan pada kanker payudara mengempis dalam rentang makin sering minumnya seperti grafik berikut

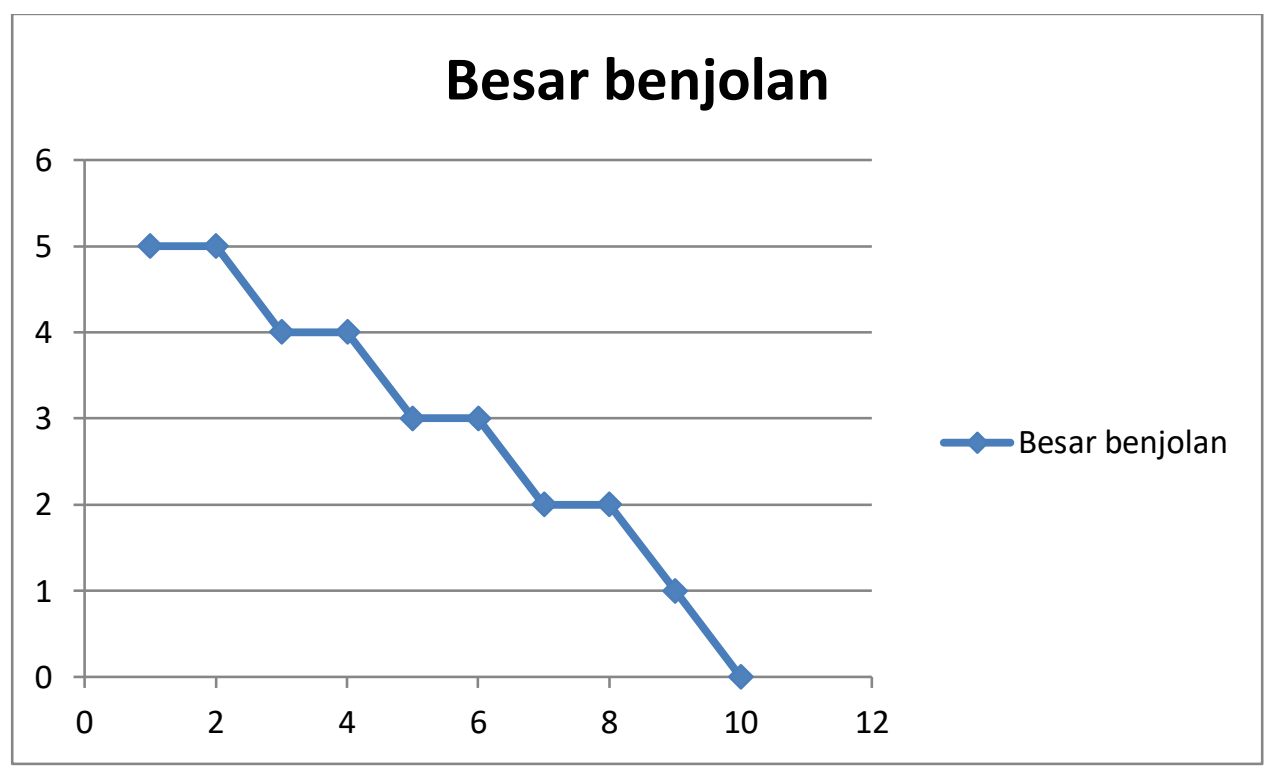


Ket:

5= benjolan besar keras, 4=benjolan besar, 3=benjolan mengecil, 2=benjolan kecil, 1=benjolan mulai menghilang, $0=$ benjolan tidak ada lagi.

\section{Kesimpulan}

Ekstrak kunyit putih dapat menyembuhkan penyakit kanker,dibuat dari kunyit putih dengan air sebanyak $200 \mathrm{ml}$. ekstrak ini dapat menyembuhkan penyakit penyakit kanker dan sakit perut saat haid setelah 10x peminuman. Seperti cerita pengalaman penderita kanker,ia terbebas dari penyakit kanker setelah 10x meminum ekstrak kunyit putih. Ekstrak ini baik diminum berkelanjutan untuk mencegah timbulnya penyakit kanker, ekstrak ini dapat menyembuhkan kanker karena terdapat zat ribosome inactivating protein (RIP), yang dapat menempel pada sel bermasalah yang berkembang sehingga sel tersebut dapat berhenti berkembang, dan kemudian musnah akibat tidak dapat berkembang biak lagi. 


\section{REFERENSI}

[1] Chifdhiyah, Alina Nuru.2012.PENGARUH PENAMBAHAN EKSTRAK KUNYIT PUTIH (Kaempferia rotunda) TERHADAP JUMLAH TOTAL HEMOSIT DAN AKTIFITAS FAGOSITOSIS UDANG WINDU (Penaeus monodon) Journal of Aquaculture Management and Technology. Vol 1, No 1

[2] Dwi Wijayanti, Agustina , Fumia Maria, Alian, Nur Khasanah, Siti.2011.PENGARUH PEMBERIAN EKSTRAK KUNYIT PUTIH (Curcuna alba) TERHADAP NILAI Hb (Hemoglobin), PCY (Packed Cell Volume), JUMLAH DAN DIFERENSIAL LEKOSIT TIKUS YANG TERPAPAR ASAP SEPEDA MOTOR. Jurnal Sain Veteriner.Vol 1, No 29

[3] Rodiansono, Rodiansono, Adam, Sulfi, Santoso, Uripto Trisno. 2008. Kajian Aktivitas Katalis Ag/Zeolit-Tio2 Pada Degradasi Fotokatalitik Fenol Menggunakan Lampu UV. Jurnal Sains dan Terapan Kimia. Vol 2, No 1 Hermawanti,Laily.2015.PENGGABUNGAN

ALGORITMA BACKWARD ELIMINATIONDANNAIVE BAYES UNTUK MENDIAGNOSIS PENYAKIT KANKER PAYUDARA. MOMENTUm.Vol 11, No 1

[5] Muliani, Hirawati .2010.Struktur Mikroanatomi Ren Ayam (Gallus Sp.) karena Pengaruh Pemberian Kunyit Putih (Curcuma Zedoaria). JURNAL ANATOMI FISIOLOGI. Vol 18, No 2

[6] Sari, A. (2017) "POTENSI ANTIOKSIDAN ALAMI PADA EKSTRAK DAUN JAMBLANG (Syzigium cumini (L.) Skeels)”, EKSAKTA: Berkala Ilmiah Bidang MIPA, 18(02), pp. 107-112. doi: 10.24036/eksakta/vol18-iss02/61. 
[7] Murniaty.2010.Peningkatan Aktivitas dan Hasil Belajar Kimia Melalui Kombinasi Metode Diskusi Dan Latihan Berstruktur (telaah pada pokok bahasan tata nama dan persamaan reaksi kimia) C H E M I C A. Vol 11, No 2

[8] Chairi, I., E., \& Zainul, R. (2018, September 19). Pengembangan LKS dengan Pendekatan Saintifik Berbasis Discovery Learning Pada Materi Hukum Dasar Kimia untuk Pembelajaran Kelas X SMA/MA. https://doi.org/10.31227/osf.io/xnbtv

[9] Chatri, M., Mansyurdin, M., Bakhtiar, A. and Adnadi, P. (2017) "PERBANDINGAN KOMPONEN MINYAK ATSIRI ANTARA DAUN MUDA DAN DAUN DEWASA PADA HYPTIS SUAVEOLENS (L.)POIT”, EKSAKTA: Berkala Ilmiah Bidang MIPA, 18(02), pp. 112. doi: 10.24036/eksakta/vol18-iss02/41.

[10] Horiza, H., Azhar, M. and Efendi, J. (2017) "EKSTRAKSI DAN KARAKTERISASI INULIN DARI UMBI DAHLIA (Dahlia sp.L) SEGAR DAN DISIMPAN”, EKSAKTA: Berkala Ilmiah Bidang MIPA, 18(01), pp. 31-39. doi: 10.24036/eksakta/voll8-iss01/14.

[11] Prabowo, H. (2018) "PENYELIDIKAN KELAYAKAN KIMIA DAN PENYEBARAN CADANGAN PASIR BESI DAERAH TIKU KABUPATEN AGAM UNTUK BAHAN BAKU SEMEN PADA PT. SEMEN PADANG”, EKSAKTA: Berkala Ilmiah Bidang MIPA, 19(1), pp. 39-42. doi: 10.24036/eksakta/vol19-iss1/121.

[12] Sanjaya, H. (2017) "DEGRADASI METHYLENE BLUE MENGGUNAKAN KATALIS ZnO-PEG DENGAN METODE FOTOSONOLISIS”, EKSAKTA: Berkala Ilmiah Bidang MIPA, 18(02), pp. 21-29. doi: 10.24036/eksakta/vol18-iss02/45. 
[13] Christanti, Jessica ,Prasetyo, Awal.2012.Tingkat Ketahanan Hidup Penderita Kanker Nasofaring pada Berbagai Modalitas Terapi Studi Kasus yang Menjalani Terapi Konvensional dan Pengobatan Komplementer Alternatif. MEDIA MEDIKA INDONESIANA.VOLUME 46

[14] Tutuarima, T. (2017) "SIFAT FISIK DAN KIMIA MARMALADE JERUK KALAMANSI (Citrus microcarpa) : KAJIAN KONSENTRASI PEKTIN DAN SUKROSA Physical and Chemical Properties of Marmalade Citrus of Calamondin (Citrus microcarpa) : Study of Pectin and Sucrose Concentrations", EKSAKTA: Berkala Ilmiah Bidang MIPA, 18(02), pp. 164-172. doi: 10.24036/eksakta/vol18-iss02/73.

[15] Azhar, M., Ahda, Y., Ihsanawati, I., Puspasari, F., Mawarni, S., Risa, B. and Natalia, D. (2017) “SKRINING BAKTERI PENDEGRADASI INULIN DARI RIZOSFER UMBI DAHLIA MENGGUNAKAN INULIN UMBI DAHLIA", EKSAKTA: Berkala Ilmiah Bidang MIPA, 18(02), pp. 13-20. doi: 10.24036/eksakta/vol18-iss02/44.

[16] Siti Rofida. Oktober 2010 - Maret 2011

.PERANAN MIKROBA ENDOFIT UNTUK PENGEMBANGAN OBAT ANTI KANKER. Jurnal Farmasains. Vol 1, No 2

[17] Riyasa, I Ketut T, Notosiswoyo, R. Mulyono. 30 January-April 2004 .Keterkaitan antara Karakteristik Penderita Kanker Payudara dengan Upaya Pengobatan Tradisional. Jurnal Kedokteran Meditek.vol. 12 no. 30

[18] Hidayah, Setya Nurul.2013.PENGARUH TINGKAT PENGETAHUAN TENTANG PENGOBATAN KEMOTERAPI TERHADAP TINGKAT KECEMASAN PASIEN KANKER DI RUANG SITOSTATIKA RUMAH SAKIT TELOGOREJO SEMARANG. Karya Ilmiah S.1 Ilmu Keperawatan 
[19] Sumarmin, R. (2018) "Pengaruh Ekstrak Kulit Buah Manggis (Garcinia mangostana L.) terhadap Histologis Pankreas Mencit (Mus musculus L. Swiss Webster) yang Diinduksi Sukrosa", EKSAKTA: Berkala Ilmiah $\quad$ Bidang $\quad$ MIPA, $\quad 19(1), \quad$ pp. $\quad$ 100-112. doi: 10.24036/eksakta/vol19-iss1/123.

[20] Iskandar, I., Horiza, H. and Fauzi, N. (2017) "EFEKTIVITAS BUBUK BIJI PEPAYA (Carica Papaya Linnaeaus) SEBAGAI LARVASIDA ALAMI TERHADAP KEMATIAN LARVA AEDES AEGYPTY TAHUN 2015”, EKSAKTA: Berkala Ilmiah Bidang MIPA, 18(01), pp. 12-18. doi: 10.24036/eksakta/vol18-iss01/12.

[21] Mulia, M. (2017) “ISOLASI KUMARIN DARI KULIT BUAH LIMAU SUNDAI (Citrus nobilis Lour)", EKSAKTA: Berkala Ilmiah Bidang MIPA, 18(02), pp. 137-145. doi: 10.24036/eksakta/vol18-iss02/70.

[22] Dinata, M. and Soehardi, F. (2018) "Factor Analysis of Physics Chemistry Waters that Affects Damage Safety Cliff on the Outskirts of River Siak", EKSAKTA: Berkala Ilmiah Bidang MIPA, 19(2), pp. 46-49. doi: 10.24036/eksakta/vol19-iss2/143.

[23] Joebaedi, K. (2018) "MODEL STAR(1;1) PADA DATA PRODUKTIVITAS TEH”, EKSAKTA: Berkala Ilmiah Bidang MIPA, 19(1), pp. 35-38. doi: 10.24036/eksakta/vol19iss $1 / 118$.

[24] Zainul, R., \& Prima, C. B. (2018, December 9). TEKNOLOGI MATERIAL MAJU Prinsip Dasar dan Aspek Rekayasa. https://doi.org/10.31227/osf.io/p63wc 
[25] Rizki Saputra, M. and Sumarmin, R. (2018) "PENGARUH EKSTRAK DAUN SIRIH MERAH (Piper crocatum Ruiz \& Pav.) TERHADAP GLUKOSA DARAH MENCIT (Mus musculus L.) JANTAN YANG DIINDUKSI SUKROSA”, EKSAKTA: Berkala Ilmiah Bidang MIPA, 19(1), pp. 43-55. doi: 10.24036/eksakta/vol19-iss1/124.

[26] Hidayat, D. (2018) “ANALISIS RESPON PENGONTROL ON-OFF PADA KENDALI UMPAN BALIK SISTEM FISIS ELEKTRONIK", EKSAKTA: Berkala Ilmiah Bidang MIPA, 19(1), pp. 118-124. doi: 10.24036/eksakta/vol19-iss1/119.

[27] Dinata, A. A., Rosyadi, A. M., Hamid, S., \& Zainul, R. (2018, October 15). A Review CHEMICAL VAPOR DEPOSITION : PROCESS AND APPLICATION. https://doi.org/10.31227/osf.io/yfeau

[28] Rahmi H.G, I. (2017) "TELAAH FAKTOR-FAKTOR YANG MEMPENGARUHI STATUS GIZI BALITA DI KOTA PADANG BERDASARKAN BERAT BADAN PER TINGGI BADAN MENGGUNAKAN METODE CART”, EKSAKTA: Berkala Ilmiah Bidang MIPA, 18(02), pp. 86-99. doi: 10.24036/eksakta/vol18-iss02/59.

[29] P, O. M., A, L. G., S, A. Y. M., \& Zainul, R. (2018, October 12). A Review Grinding : Teknik dan Prinsip Dasar pada Pengolahan Material. https://doi.org/10.31227/osf.io/trv4q

[30] Febriani, S. S., Yolanda, T., Arianti, V. A., \& Zainul, R. (2018, October 12). A Review Solid Stated : Principles and Methode. https://doi.org/10.31227/osf.io/7us4x

[31]R Zainul, B Oktavia, I Dewata. 2017. Studi Dinamika Molekular dan Kinetika Reaksi pada Pembelahan Molekul Air untuk Produksi Gas Hidrogen

[32] Zainul, R. (2019, January 15). f. https://doi.org/10.31227/osf.io/75pdj 
[32] Liza, Y. M., Yasin, R. C., Maidani, S. S., \& Zainul, R. (2018, October 9). SOL GEL : PRINCIPLE AND TECHNIQUE (A REVIEW). https://doi.org/10.31227/osf.io/2cuh8

[34] Zainul, R. (2018, August 16). Design and Modification of Copper Oxide Electrodes for Improving Conversion Coefficient Indoors Lights (PV-Cell) Photocells.

https://doi.org/10.31227/osf.io/pgn84

[35] Z Chaidir, R Zainul, D Nurakhbari, M Salim. 2016. Optimization of Spirulina Platensis Culture for Antioxidant Production 